\title{
LEPROSY CONTROL IN THE OWERRI PROVINCE, SOUTHERN NIGERIA
}

\author{
T. F. DAVEY
}

\section{A. AIMS AND POLICY}

The aim of the Uzuakoli Leprosy Settlement may be stated in few words. It is the eradication of leprosy from the Owerri Province of Nigeria. The realisation of this aim lies in the distant future, and before it is reached immense problems have to be solved. All the same, a start has been made, general principles have been laid down, methods of policy have been tested and proved, and the attack on leprosy which began as an experiment in 1939 has gathered ever increasing impetus and in some parts of the Province is piercing to the very roots of the problem. This report describes the progress made up to the end of I94I.

The principles of leprosy control with which there is general agreement are now becoming well defined. They are embodied in the scheme of control which we have elaborated for the Owerri Province, but are adapted to meet the conditions peculiar to the area concerned.

The features of our programme are as follows:

I. The provision of Leprosy Clinics where patients may receive the best possible treatment and care free of charge.

2. Intensive Leprosy Surveys of clans where the people are anxious to co-operate, and where clinics already exist.

3. Voluntary segregation of infectious cases of leprosy in Model Villages attached to clinics with Resident Nurses (male), leading to full leprosy control, 
4. Oversight of clinics and control schemes by trained Leprosy Inspectors.

5. Propaganda of all types.

Within these broad outlines there is ample room for adaptation to local conditions. No rigid scheme will meet the situation. Each District has its own peculiar problems, and it is necessary to suit the type of work proposed to the thought and needs of the people in the locality.

Each of these five lines of attack will be discussed in the following pages, and a review will be given of the situation in the four Divisions of the Province where work is being carried out at present.

\section{Priliminary Notes}

The Owerri Province is one of the largest and most densely populated among the Southern Provinces of Nigeria. Extending from the coast inland for about I50 miles, and having a width of about 60 miles, it may be divided geographically into three belts.

(a) In the South, a large area of swamp and creek composing part of the Niger Delta, and including Degema and part of Ahoada Divisions. The population is sparse, communications difficult, and the area is untouched by our work.

(b) A low lying plain occupying the central parts of the Province, and supporting a dense rural population rising in places to $\mathrm{I}, 000$ to the square mile. Here the incidence of leprosy is variable. but increases towards the North.

(c) In the North, there is a range of hills with deeply eroded valleys, partly forest, partly savannah. Here conditions of life are harder, and the leprosy incidence reaches its maximum, figures as high as ro per cent of the population not being exceptional. It is in this area that the greater part of our work is concentrated, in the Bende and Okigwi Divisions.

MAP I. is a sketch map of the Province, showing the Divisions and the centres where leprosy work is being carried out.

\section{B. LINES OF ATTACK}

\section{(1) Leprosy Clinics}

The first line of attack against leprosy in the Owerri Province is found in the provision of Clinics for the treatment of leprosy. There are now no less than 29 of these, distributed as follows:Bende Division I4 (including the Central Settlement). Okigwa Division 9

Aba Division 3

Ahoada Division 3 


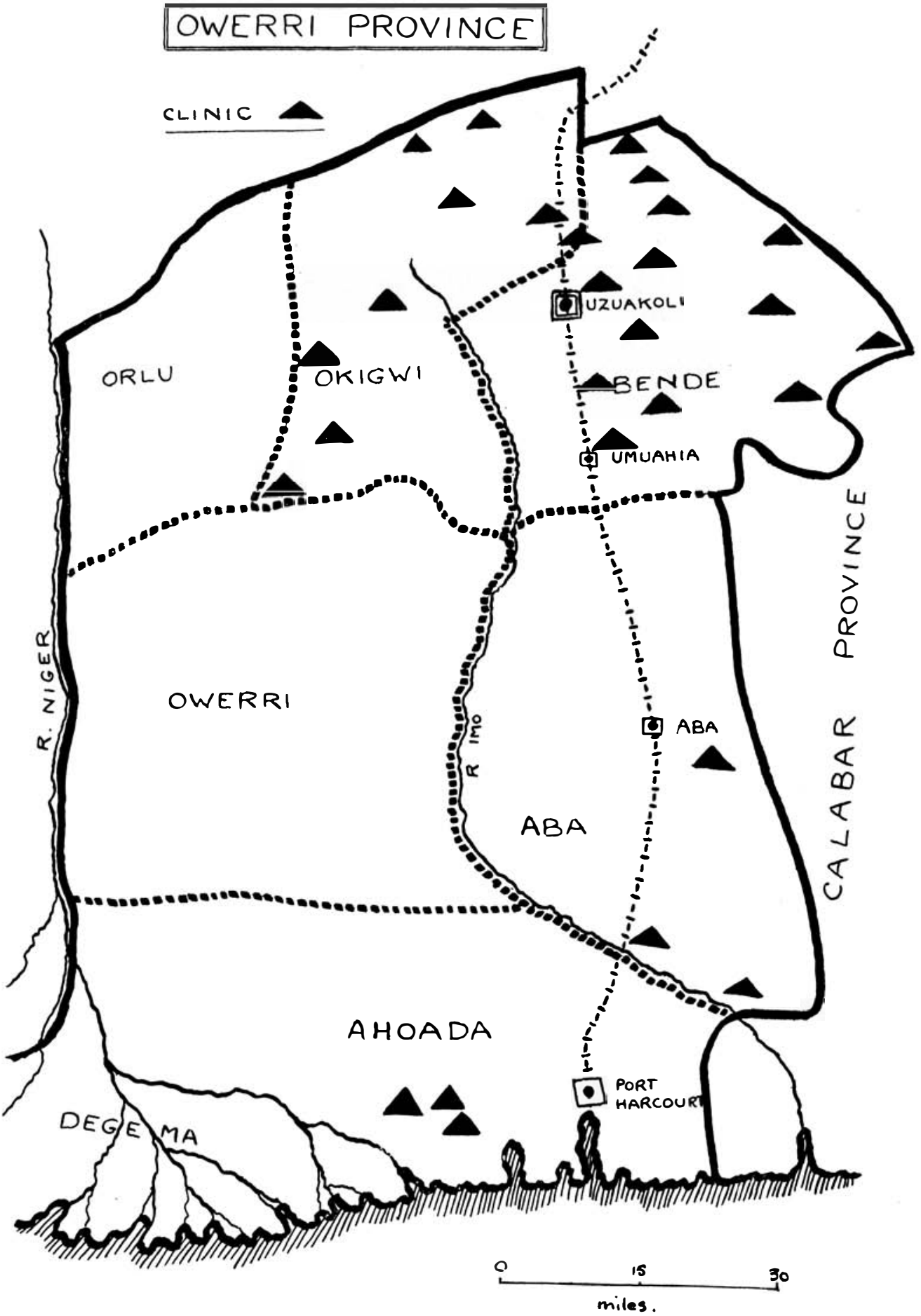


At these centres, more than 7,000 patients are attending regularly for treatment, while a further $\mathrm{I}, 000$ are being kept under observation. Exact statistical details are given later.

The position of the clinics are marked in MAP I.

\section{Clinic Organisation}

The clinic is simply a suitable site by the side of a motor road where persons suffering from leprosy gather for treatment. No elaborate buildings are necessary, and indeed in all cases have been provided free of charge either by chiefs or by patients themselves. No rent is paid for the site, the owners offering the land freely for the good of their clan. The people thus feel that the clinic belongs to them, and not to us, and the first step in winning their co-operation is achieved. Clinics have usually three buildings, a treatment hut, an ulcer dressing hut, and a waiting room.

The early days of a clinic witness many distressing scenes which would be a revelation to anyone unfamiliar with the situation. On the appointed morning a motley crowd of lepers gathers at the site, unkempt, hopeless, penniless and in rags; many have dragged themselves along with the aid of sticks, their untreated sores an eloquent testimony to their neglected condition. There is little noise, most of the patients exhibiting that apathy common to Ibo lepers, the result of the contempt and ostracism with which they are regarded. Nigeria's " untouchables " are revealed in all their misery.

The patients are registered, temperatures taken, leprosy treatment given, ulcers are dressed, advice given regarding personal hygiene, and in a few weeks a miracle occurs. Ulcers often undressed for years respond to regular treatment, self-respect is reawakened, disorder gives place to discipline, and the clinic becomes a place of cheerfulness and hope. Patients seriously ill are carried to Uzuakoli for hospital treatment. Capable patients give assistance to the nurse, others become 'policemen,' and the flow of the new patients, slow at first, rapidly becomes a flood. With returning self-respect there comes a demand for redress for wrongs formerly suffered in silence, debts unpaid, land and goods confiscated, dowries unrefunded, and so on. To his fellows, a leper is often outside the law, but through the magnificent co-operation of District Officers, many a patient has found justice, and a healthy respect has been born in the minds of non-lepers for our work.

These and other services lead to a sense of gratitude in the minds of the patients, who become eager to co-operate in any measures for leprosy control which we suggest. This is a vital matter, for no leprosy control is possible until the patients themselves are willing to assist in making it effective. 
This story is reproduced with almost monotonous regularity with each new clinic, and the clinic thus takes its place as a vital step in the achievement of leprosy control.

We now come to the end of the story.

During 194I, 223 patients have been discharged symptom free, 79 of them from the Uzuakoli Settlement and I44 of them from cuncs. This latter group have been treated exclusively at Clinics and have never been to Uzuakoli.

Thus are clinics triumphantly justified.

The Clinics vary greatly in size, the largest, at Cturu, having nearıy 900 patients. The population of the Owerri Province is both dense and fairly evenly distributed, and consists, for the most part, of many small clans, each decidedly clan conscious. I here is widespread opposition to lepers travelling through the territory of a neighbouring clan in order to reach a climc, and our policy has therefore been to establish many small clinıcs, mainly on a basis or ai least one to a clan, rather than a few large clinics. The goodwill of the people has thus been retained and lepers have had the maximum encouragement to attend clinics. Throughout the Bende Division there are tew areas where lepers have to walk more unan five miles to a clinic. Advanced cases are thus not involved in any untoward degree of discomfort in attending clinics and regular attendance is made possible. This is an important consıderation when leprosy control measures are in operation as will be indicated later.

At many of the clinics there are resident nurses, and their appointment is an integral part of our policy, as it permits of work of a high degree of efficiency being carried out. One example will suffice. Many patients suffer from ulcers, and no radical improvement in their conditions, as far as leprosy is concerned, may be hoped for until ulcers are properly treated. With a nurse resident at the clinic, patients may receive dressings daily where these are needed. The nurse also prepares for the weekly visit of the Medical Officer and his staff from Uzuakoli, visits absentee patients, and when a model village is built, he becomes the natural leader of the patients.

\section{Limits to the Uslefulness of Clinics}

It must not be imagined that clinics offer a radical solution to the leprosy problem. As a means of providing leprosy relief on a large scale their value cannot be overestimated, but their contribution to leprosy control is small. Although large numbers of patients are improved in health and many early cases may be cured, the infectious lepromatous cases are not greatly influenced by 
clinic treatment except in isolated cases. These remain active sources of danger to healthy people in spite of their treatment and it is therefore futile to rely on clinics as a means of stamping out leprosy. If any improvement in the situation is to be hoped for in a reasonable time, more active measures are necessary.

The functions of a clinic may be summarised as follows:-

I. To provide free leprosy treatment to patients near their homes.

2. To be a source of leprosy propaganda.

3. To form some estimate of the leprosy problems in the neighbourhood.

4. To win the confidence and co-operation of both patients and healthy people and so prepare the way for future work.

At first we met with considerable opposition when trying to open clinics. Now requests for new clinics are becoming more numerous and new clinics are being opened at the rate of one per month. At least six more are visualised in the immediate future. A point is now being reached when requests for new clinics must be met with a refusal, as we have not the staff available for supervising them.

\section{LEPROSY SURVEYS}

When a clinic has been established and both lepers and healthy people are ready to co-operate, the way is prepared for active leprosy control measures, the next step in which is the Leprosy Survey. By submitting the entire population to medical examination, accurate statistics regarding leprosy incidence and type can be obtained, and the extent of the problem reckoned exactly. With a record made of all infectious cases, data vital to leprosy control are obtained and all is ready for the next step.

Leprosy surveys are by far the most difficult feature of our work, but are the only basis on which effective leprosy control can be built. The first revelation which a survey makes is that the number of patients attending the clinic is no real guide to the actual incidence of leprosy. There are two classes of patient who do not attend clinics in representative numbers. These are (I) the very advanced case who fails to attend through sheer infirmity, and (2) the very large group of early cases.

When a man is discovered to be suffering from leprosy, the loss of social status and prestige which he suffers is dreaded far more than the suffering which the disease itself produces. All patients therefore endeavour to conceal their disease as long as possible. When a man attends for treatment at the Clinic, doubts in the 
minds of his neighbours become certainties and he bows to the inevitable. Early cases can still conceal their disease, and are consequently not adequately represented at the clinic. They are easily discovered during a survey.

It may be asked, "Why do these people not hide themselves during a survey?" The answer is simple. The survey is only held when a large majority of the people want it, and many local people assist in it. The survey is conducted from house to house. The chiefs have ordered that on a certain day everyone must stay at home for medical examination. Any person who absents himself is at once regarded with suspicion, and public opinion demands his examination later.

The early cases thus discovered are a most important group. They normally go for treatment secretly to a native doctor and some are certainly rendered symptom free by the cautery and caustics which native doctors employ. At the same time, this is precisely the group whose treatment at Clinics is most desirable for $100 \%$ cures can be expected. Indeed, most of the patients we have discharged from clinics come from this group, and their successful treatment enormously enhances the prestige of the clinic.

In our experience only about one-third of the lepers in an area attend a clinic on their own initiative, and the remainder have to be discovered by means of a survey. For every advanced case there are at least six to ten very early cases, and it is necessary to count lepers in tens of thousands in the Owerri Province in order to obtain even a rough estimate of the huge numbers of patients at large in the Province.

A survey is of little value unless it is thorough, and its carrying out is both physically and mentally exhausting. Much denends on team work, and we have built up a team of workers capable of carrying out intensive surveys with full bacteriological control. The ground to be covered is so vast that this work must fall increasingly on the shoulders of Africans, and Leprosy Inspectors are now to receive training in this aspect of their work.

A considerable number of surveys has now been carried out, as the following statistics indicate.

$\begin{array}{llcc}\text { Clan } & \text { Village } & \begin{array}{c}\text { Population } \\ \text { Examined }\end{array} & \begin{array}{c}\text { Ieprosy Incitence } \\ \text { (percentage) }\end{array} \\ \text { Ozuitem } & \text { Ebem } & \text { rog } & 4.6 \\ & \text { Elugwu Mba } & 240 & 3.3 \\ \text { Ndi Agho } & 794 & 3.4 \\ & \text { Amankwo } & 145 & 3.4 \\ & \text { Amagbo } & 248 & 6.1 \\ & \text { Mba } & 389 & 3.9\end{array}$




\begin{tabular}{|c|c|c|c|}
\hline \multirow[t]{3}{*}{ Clan } & Village & $\begin{array}{l}\text { Population } \\
\text { lixamined }\end{array}$ & $\begin{array}{l}\text { Leprosy Incidenic } \\
\text { (percentage) }\end{array}$ \\
\hline & Oboko & I772 & I. 5 \\
\hline & Mbele & $\mathrm{I} 85$ & $4 \cdot 3$ \\
\hline \multirow[t]{2}{*}{ Isiegbu } & Amaeke & $36 I$ & I I. 8 \\
\hline & Umueze & 288 & 9.6 \\
\hline \multirow[t]{2}{*}{ Nkporo } & Etiti Ama & I 892 & 6.2 \\
\hline & Ama Orie & I3I 2 & $5 \cdot 9$ \\
\hline \multirow[t]{7}{*}{ Abam } & Ndi Oji & I I 45 & I2.9 \\
\hline & Atani & 1022 & 8.5 \\
\hline & Ndi Okereke & 492 & II.7 \\
\hline & Ahuma & I43 & 8.6 \\
\hline & Aziafo & I 59 & I 5.2 \\
\hline & Ndi Okorie & 221 & I 2.2 \\
\hline & Ndi Okpara & 77 & 9.I \\
\hline
\end{tabular}

Bende

Totals for I4 villages 2829

$\begin{array}{llrl}\text { Umu-Imenyi } & \text { Akaelu Lodu } & 507 & 6.4 \\ \text { Ohuhu } & \text { Umuakam } & 249 & 3.6 \\ & \text { Umuosu } & 429 & \text { I.4 } \\ & \text { Umuleweze } & 86 & \text { I.3 } \\ \text { Item } & \text { Amaeke } & \text { I } 402 & 2.7\end{array}$

Abua The entire clan was surveyed, but without bacteriological control. Original figures were later adjusted as follows:

$$
\text { I } 4,5 \mathrm{I} 5
$$

With the exception of Abua, all the areas surveyed are in the Bende Division. Attention should be drawn to the appallingly high incidence in some clans, notably in Abam and in Isiegbu Ozuitem.

\section{(3) VOLUNTARY SEGREGATION IN MODEL VILLAGES}

With a clinic established and a survey completed, all is ready for the vital step in leprosy control. The spread of leprosy is attributed to a multitude of causes, overcrowding, under-nourishment, debilitating diseases, bad sanitation and so on. It cannot be too strongly emphasised that these are secondary causes only, and only operate provided that the germ of leprosy is present, or in other words, provided that persons suffering from contagious leprosy are living among the general population. If contact between these persons and healthy people is prevented, it is impossible for leprosy to spread, as the disease cannot be reproduced in the absence of the lepra bacillus. By dint of improving diet and hygiene, the susceptibility of the race to leprosy may gradually be 


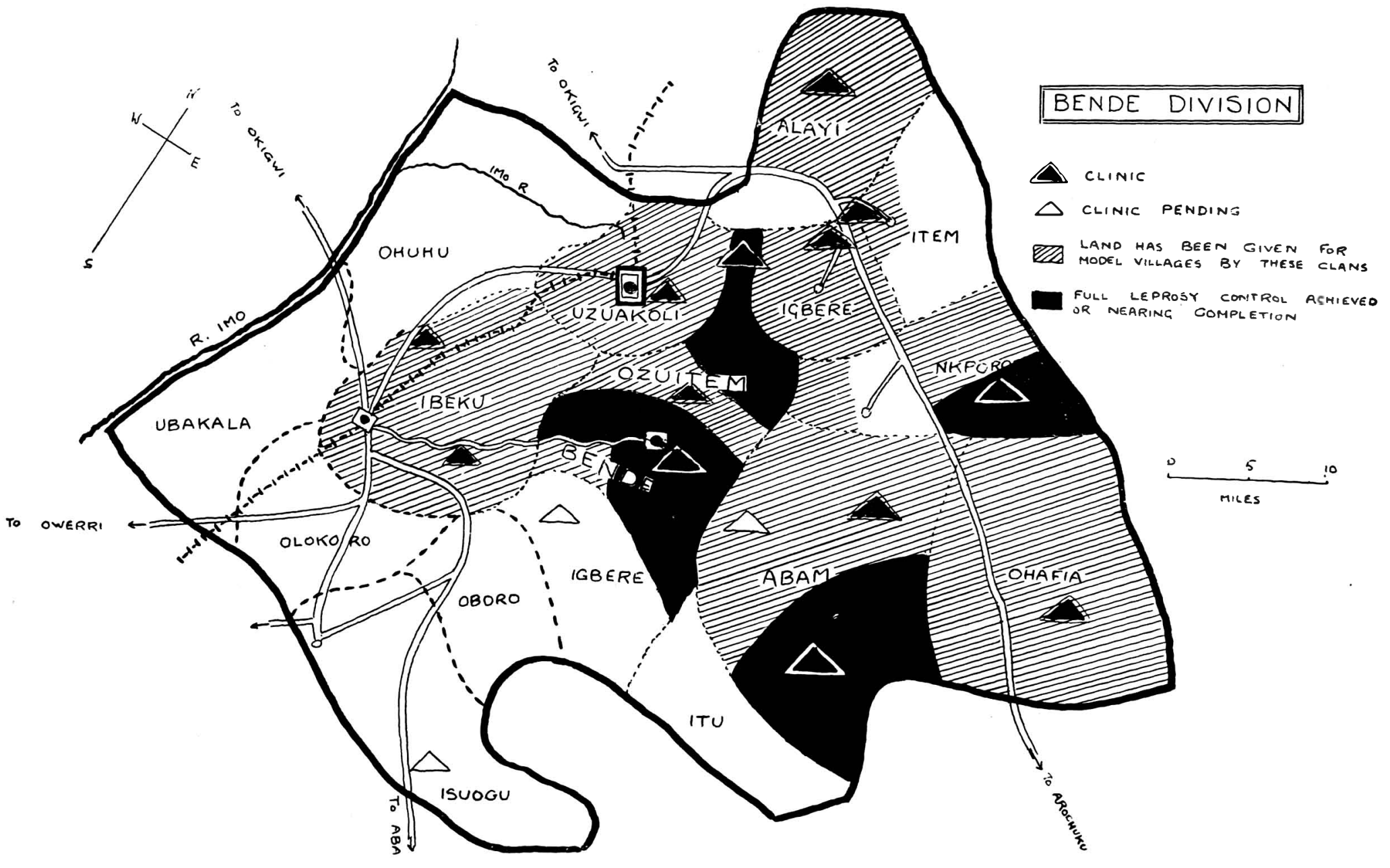


lessened, but there is smail profit if during the decades needed for its achievement, infectious cases of leprosy are spreading the disease far and wide.

All authorities ciyre that segregation of infectious cases is the one vital step in leprosy control, but opinions differ as to the best methods to be adopted, as the goal, namely the segregation of ALL infectious cases is elusive.

Methods of compulsion are doomed to failure as unwilling patients make every effort to conceal themselves.

The only mithod which commends itself is to make segregation a voluntary matter, but make it so attractive that patients, instead of droadiny it, actually ask for it.

This highly desirable object is not a theory or a dream of the future. In the Owerri Province it is very much within the realm of actual practice. Already, more than 2,000 patients have voluntarily segregated themselves and hundreds more are waiting to do so as soon as accommodation becomes available.

The method employed is as follows:

Following the establishment of a clinic, chiefs are asked to offer freely an area of land where patients can live. Good land is demanded, close to drinking water and not more than three miles from the villages from which patients are drawn. No rent is paid. When the land has been approved, the clinic if distant is moved to its proximity. Healthy people help to clear the land and then the patients are enlisted for work one or two days a week. This has an excellent effect both physically and mentally and aids the co-operate spirit. One house is built on the site and here the nurse comes to live. A model village is now planned to suif the site, and as houses multiply they are occupied by patients who desire to live there. Chiefs provide building materials, and houses, latrines, incinerators, etc., are constructed of local materials and are designed to provide an object lesson to healthy people in village lay out and sanitation. A valuable contribution :s thus made to the sanitary education of the community. Patients with few exceptions are eager to move to new quarters, for advantages are many. Sanitary surroundings lead to physical fitness, there is a nurse on the spot to attend to ulcers, etc., patients are still within easy reach of their farms, and in the new community there is none of the ostracism and unhappiness with which they are only too familiar in the towns.

It must be emphasised that the first and most important inhabitant of the village is the nurse attached to the local clinic. He acts as leader and supervisor until such time as a suitable headman can be discovered, but always retains his post as sanitary supervisor. 
In some instances suitable persons have been sent from Uzuakoli to act as headman. This supervision by trained assistants is a vital necessity.

There are already ro village Settlements of this type, made beautiful with lawns and flower beds, and some of them are among the most attractive villages in Nigeria.

In some areas the process of voluntary segregation has gone on to its logical conclusion, and every known case of infectious leprosy is segregated. We are entitled to claim that leprosy control has actually been achieved in these areas, and the machinery has now been produced for maintaining this highly desirable state of things indefinitely.

\section{LEPROSY INSPECTORS AND THEIR WORK}

The area within which clinics can be maintained and leprosy control work supervised directly from Uzuakoli is limited to a circle with a radius of about 30 miles. This is but a small part of the Province, in the whole of which a figure of 50,000 is almost certainly too low an estimate for the leprosy incidence. How may these vast multitudes of patients be reached? It is extremely doubtful whether there will ever be adequate numbers of Europeans to supervise leprosy work on the scale which is necessary. Much of the work is of a routine nature, and can safely be left in African hands. We have therefore created a class of men known as Leprosy Inspectors who are destined to play a vital part in the future programme of leprosy control. These men are non-lepers and are made responsible for leprosy work in a limited area only. Their duties are as follows:-

(I) To keep registers and supervise up to 3 Clinics.

(2) To trace patients to their homes and advise them regarding the avoidance of contact where necessary.

(3) To undertake propaganda, visit schools, compounds and courts.

(4) To undertake localised leprosy surveys.

(5) To supervise the model villages and act as their sanitary inspectors.

(6) To give sanitary advice to healthy people, working in cooperation with the local sanitary inspector.

(7) When leprosy control has been established, to maintain it by annual surveys and the examination of newcomers.

The first course of training for these men was held in I940, 
and the Health Department co-operated in it. Two courses will be needed during 1942. At present five of these men are at work and their appointment has made possible the efficient running of clinics and villages at places remote from Uzuakoli. The work in these areas is visited once monthly, when any necessary oversight and guidance are given, new patients examined and so on.

Already the success of the work of these men may be described as brilliant, for some of our best work is being carried out where these men are stationed. Surveys have been undertaken by them in which thousands of people have been examined, and we are convinced that the appointment of these men should be regarded as a vital feature of the programme of leprosy control. As their numbers increase it will be possible to carry leprosy control to the remotest parts of the Province.

Their function of maintaining leprosy control once it has been established is of great importance. Even with a large staff, the survey of the whole Province would take many years to complete. Control needs annual surveys to maintain its effectiveness. These men, each working in a limited area offer the solution to this problem. The local people are soon known personally to them and surveys are carried out even more effectively than is possible to a visiting team of workers who are strangers to the people.

Leprosy control is a key problem, with which are bound up all those sanitary and economic problems the solution of which seems so remote in Southern Nigeria. Many clans have not the funds necessary for the provision of a sanitary inspector but there are few who cannot afford to have a Leprosy Inspector, and the possibilities inherent in the appointment of these men are so great that every effort should be made to facilitate the increase of their numbers.

\section{PROPAGANDA}

Although Ibos have an uncanny ability to diagnose leprosy, there is widespread ignorance of the facts regarding the disease, and propaganda is therefore an important feature of our work. Actual methods employed include the following :-

\section{A. Propaganda for Those Who Can Read}

There is everywhere considerable readiness to believe anything seen in print. $\Lambda$ booklet, "What Everybody should know about Leprosy," has been prepared and a small test edition was exhausted immediately it appeared. It is hoped that a larger and improved edition will be printed. Posters have been printed and sent to Missions, N.A. Treasuries, schools and courts. 


\section{B. Propaganda by Leprosy Inspectors}

Excellent propaganda is being carried out by Leprosy Inspectors. Many visits to schools, compounds and courts have been made. This type of work will inevitably fall more and more on African shoulders.

\section{Propaganida for Illiterate People}

Where illiterate people are concerned, by far the most effective means of propaganda is that offered by successful clinics and model villages. Improvement in the condition of the patients soon awakens the interest of non-lepers to whom this is a miracle. Persons suffering from leprosy in neighbouring clans begin to pester their chiefs to do something to improve their lot and have even threatened aggressive action. Scandalised chiefs have offered land on more than one occasion because local lepers threatened to make nuisances of themselves, and when the clinics have been established they have ultimately come to thank us for the results achieved.

Numerous visits have been made to Clan Councils and meetings of chiefs. Here, also, District Officers have an unique opportunity for propaganda on our behalf, and it is being used to the full.

The work during 1941 in the different sub-divisions of the province can be conveniently summarised in the following table:

\begin{tabular}{|c|c|c|c|c|}
\hline Division & Clinics & $\begin{array}{l}\text { Registered } \\
\text { patients }\end{array}$ & $\begin{array}{c}\text { Discharged } \\
\text { recovered }\end{array}$ & $\begin{array}{l}\text { Model } \\
\text { villages }\end{array}$ \\
\hline Bende & 13 & 2872 & 51 & 5 \\
\hline Okigwi & 9 & 2117 & & 2 \\
\hline Aba & 3 & 401 & & \\
\hline Ahoada & 3 & 721 & 92 & 3 \\
\hline Uzuakoli Settlement & 1 & 1072 & 79 & \\
\hline Total & 29 & 7183 & 222 & 10 \\
\hline
\end{tabular}

A number of the clinics have not been open long enough to allow of recoveries; 5 more clinics were to be opened early in 1942. Five male nurses and five inspectors were already at work in the clinics. The leper villages isolate 2,000 highly infectious cases.

\section{THE PROVINCIAL LEPROSY SETTLEMENT AT UZUAKOLI}

The Provincial Leprosy Settlement at Uzuakoli was founded in 1932. It is a Native Administration Institution in which the Methodist Missionary Society is responsible for religious and social 
work. At its outset the colony was visualised as the only centre for leprosy work in the Province. It was to be an agricultural colony, and it was hoped that it would become largely selfsupporting. With greater knowledge, we can now look back and smile at the absurdity of this idea. Even with a resident population of 1,000 , the spectacle of one out of every bo lepers living in choice conditions at $u$ zuakol,, while the remaining 59 spread the disease tar and wide, is truly Gildertian. With regard to the Colony becomıng sell-supporting the position is equally diverting. For even a partial condition of selt-support to be possible, a majority of the patıents must be strong, able-bodied men capable of tarming on a large scale. 1 here can be no room for highly infectious cases weakened by their disease, for deformed cases, or for representative numbers of women and children. Thus the colony was to be filled with strong patients, most of whom were relatively unnfectious, while advanced cases, the infectious weak nodular cases, women and chiidren, were to be left in wretchedness and misery to get on as best they could. The Colony never did become self-supporting, and as long as humanity and common sense exist, it never will, and this basic fact must be accepted.

As soon as our programme of leprosy control in the Province took shape, it was realised that the whole policy of the Provincial Settlement must be brought into line with that programme. The first demand made on the Settlement was that the hospital should be made available for clinic patients, the second, that large numbers of nurses (male) should be trained. These and other demands resulted in many changes, and the Colony has now taken its place as the centre of the entire organisation. The Colony was readily adapted to its new role, thanks to the situation chosen for it by its first superintendent, Dr. Brown, and to his lay out of the site, and we are exceedingly fortunate in having a large and healthy site, eminently suited to European accommodation, with the railway as one boundary, and yet right in the heart of that part of the Province where leprosy is most rife.

The functions which the Provincial Settlement is fulfilling as the centre of the leprosy control organisation in the Province are as follows:

\section{The Administrative Centre}

It is from Uzuakoli that the whole organisation is organised and administered. All records are kept here. All hydnocarpus oil used for treatment (about 2,500 pints per annum) is processed here.

\section{Thi: Hospital Centre:}

Very many patients are found at clinics who are in urgent need 
of hospital treatment of some sort, .usually for serious ulcers. There is no place for these in the wards of general hospitals even in the few areas where such hospitals exist. In any case, no non-leper nurse would agree to care for them, so the obvious hospital centre is the Uzuakoli Settlement. The hospital here has accordingly been made available to clinic patients free of charge, and considerable numbers have received treatment there, in almost every case having been first carried to Uzuakoli by companions from the clinic. The capacity of the hospital has been strained to the limit, and there is urgent need for a new block for the accommodation of clinic patients.

3. Thl: TRAINING ChNTRE FOR LFPROSY WORKERS

This function is of the utmost importance. During I94I the following courses have been held.

(a) Training Courses for Medical Superintendents of Leprosy Settlements.

Two short courses were held, working in conjunction with Oji River Settlement.

(b) Traininy Courses for Clinic Nurses.

There are more than 70 leper nurses in training, and our clinic work is dependent on the efficiency of these. Now that there is no shortage of at any rate semi-educated patients, we are constantly raising the standard demanded of these nurses, and a course of training lasting one year, with appropriate examinations is demanded before a nurse goes to a Clinic.

(c) Training of Leprosy Inspectors.

Preliminary courses of training have been held during the year, but that part of the course in which the Health Department cooperates has not been held. Two such courses will be needed during 1942.

It is hoped in the future to have short courses of training for Sanitary Inspectors, N.A. Dressers, teachers, Court Clerks and other public workers. Nothing further can be done until a building is provided to act as a hostel for these people during their training.

\section{A Laboratory and Diagnostic Centre}

This obvious function is already fully realised. The laboratory is well equipped and thousands of tests are carried out annually. 
5. A LePROSARIUN FOR PATHENTS WHO CANNOT BE CATERLD FOR AT Clinics

These include the following types of patients:-

(a) Deformed persons unable to look after themselves.

(b) Advanced lepromatous cases.

(c) Destitute and pauper lepers.

(d) Children suffering from leprosy.

Children suffering from leprosy are often grossly neglected. At the Provincial Settlement there is a school, and every facility for their care and well-being.

These four types of patient are encouraged to come into the Settlement and are rapidly taking the place of more able-bodied persons who find that treatment at clinics near their homes is adequate. This is as it should be, but it must be stressed that a greater financial burden is thrown on the Provincial Settlement in consequence, as the four types of patient mentioned above are not able to work to any extent and so assist the finances of the Colony.

There are at present $\mathrm{I}, 072$ patients in the Settlement at Uzua. koli, and 79 have been discharged during 194I as symptom free. This large community demands an elaborate organisation for its treatment and welfare. The Settlement has all the desirable features of a large leprosarium, and improvements are constantly being made.

In this report, the emphasis has been laid upon the situation outside the Settlement where there is a crying need for leprosy control work. Had we the staff available we believe that immediate and tremendous progress could be made, and the distant goal of leprosy control throughout the Province could in fact be realised.

Nothing has been said of finance. It holds the key to the situation. The great virtue of the programme is its demand for so little in the way of funds, but the time is approaching when the present unsatisfactory arrangements will have to be reviewed and implemented if any serious attempt is to be made to face the leprosy problem in the Province. 